\title{
Ana Paula Maia e a literatura de autoria feminina: mulheres no seu (in)devido lugar
}

\author{
Ana Paula Maia and the Literature of Female Authorship: Women in Their (Un)due Place \\ Ana Paula Maia y la literatura de la autoría femenina: las mujeres en su (in)debido lugar \\ Lígia de Amorim Neves* \\ Lúcia Osana Zolin
}

\section{Resumo}

O objetivo geral do artigo é problematizar, a partir das novelas Entre rinhas de cachorros e porcos abatidos (2009) e O trabalho sujo dos outros (2009), bem como dos romances Carvão animal (2011), De gados e homens (2013) e Assim na terra como embaixo da terra (2017), de Ana Paula Maia, o modo como sua escrita literária reverbera no campo literário de autoria feminina e promove subversões ideológicas e estéticas na órbita das produções literárias contemporâneas. O aporte teórico é constituído pelos conceitos de biopolítica, de Giorgio Agamben; a tríade imaginário, simbólico e real, de Slavoj Žižek; e o referente ausente, de Carol Adams.

Palavras-chave: Ana Paula Maia, literatura de autoria feminina, subversões estético-ideológicas.

\section{Abstract}

The general aim of this article is to discuss, based on the novels Entre rinhas de cachorros e porcos abatidos (2009), O trabalho sujo dos outros (2009), Carvão animal (2011), De gados e homens (2013) and Assim na terra como embaixo da terra (2017), by Ana Paula Maia, the way her literary writing reverberates in the literary field of feminine authorship, and promotes ideological and aesthetic subversions in the orbit of contemporary literary production. The theoretical contribution is constituted by Giorgio Agambem's concepts of biopolitics, Slavoj Žižek's triad of Imaginary, Symbolic and Real, Carol Adams' absent referent.

Keywords: Ana Paula Maia, women's writings, aesthetic-ideological subversions.

\section{Resumen}

El objetivo general de este artículo es problematizar, desde las novelas cortas Entre rinhas de cachorros e porcos abatidos (2009) y O trabalho sujo dos outros (2009), así como las novelas Carvão Animal (2011), De gados e homens (2013) y Assim na terra como embaixo da terra, de Ana Paula Maia, el modo como su escritura literaria reverbera en el campo literario de autoría femenina, y promueve subversiones ideológicas y estéticas en la órbita de las producciones literarias contemporáneas. El aporte teórico es constituido por los conceptos de biopolítica, de Giorgio Agamben; la tríada de lo Imaginario, lo Simbólico y lo Real, de Slavoj Žižek, y el referente ausente, de Carol Adams.

Palabras-clave: Ana Paula Maia, literatura de autoría feminina, subversiones estético-ideológicas.

Um olhar para o século XX a partir da década de 1960 pode revelar uma efusão de propostas ético-filosóficas e literárias voltadas para a ampliação do paradigma humanista dicotômico, que não admite o conceito de alteridade, entendido como forma de reconhecer que há outras culturas além da nossa.

Assim também problematiza Agamben em sua obra $O$ aberto: o homem e o animal, a qual discute o dualismo radical que a tradição ocidental estabeleceu entre a vida biológica e a vida política. Ao iniciar seu livro com a apresentação de uma gravura da Bíblia hebraica do século XIII (Figura 1), a do banquete messiânico no último dia segundo a visão do profeta Ezequiel, em que os justos são

\footnotetext{
* Universidade Estadual de Maringá (UEM), Maringá, PR, Brasil. (Dorcid.org/0000-0001-9224-7630. E-mail: ligiadeamorim@ gmail.com ** Universidade Estadual de Maringá (UEM), Maringá, PR, Brasil. (Dorcid.org/0000-0002-8874-0251. E-mail: luciazolin@ yahoo.com.br
} 
representados com corpos humanos e cabeças de animal, Agamben questiona (2017, p. 11): "Por que os representantes de toda a humanidade são retratados com cabeças de animais?"

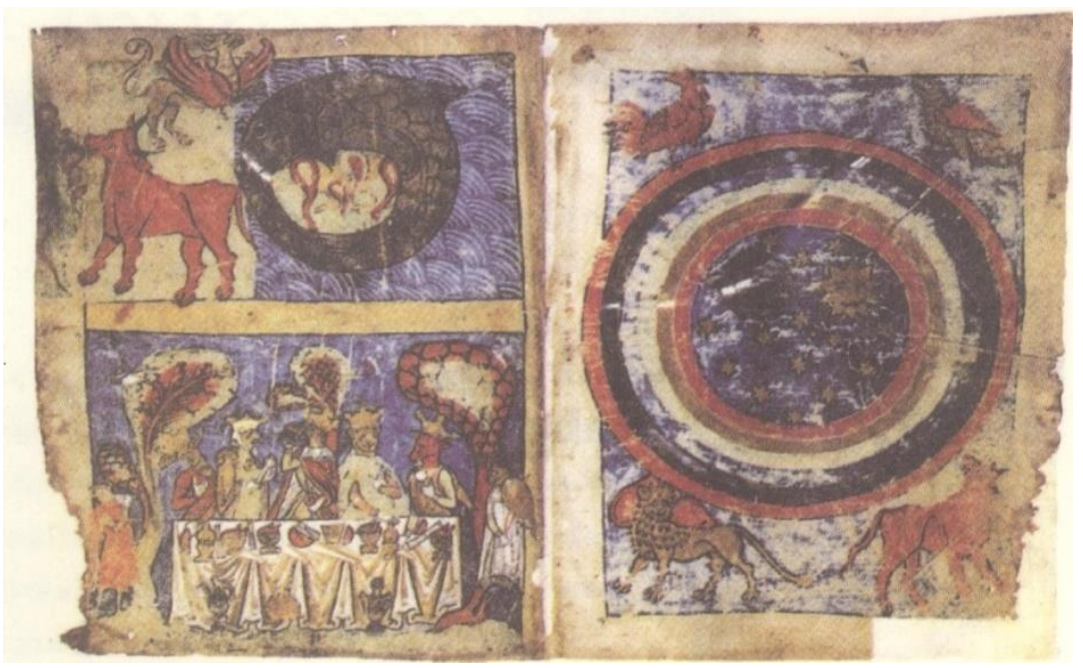

Figura 1 - Banquete messiânico no último dia

Fonte: Agamben (2017, p. 2).

Essa imagem, ao figurar uma reconciliação do humano com sua natureza animal, dissolve uma das grandes aporias que a tradição ocidental estabeleceu ao longo do tempo: a construção do ser humano como separado do animal. Estariam essas mesmas instâncias, homem e animal, na literatura de Ana Paula Maia, a serviço dessa dissolução, indicando uma abertura para a alteridade?

Para refletir sobre essa questão, tomamos o volume Entre rinhas de cachorros e porcos abatidos (2009) - composto pela novela com título homônimo e por "O trabalho sujo dos outros" -, além dos romances Carvão animal (2011), De gados e homens (2013) e Assim na terra como embaixo da terra (2017). Para demonstrar de que modo essa escrita literária reverbera no campo literário de autoria feminina, como aporte teórico, partimos dos seguintes conceitos: a biopolítica, de Giorgio Agamben; a tríade imaginário, simbólico e real, de Slavoj Žižek; e o referente ausente, de Carol Adams.

\section{"Ninguém está impune": biopolítica}

Após a Revolução Industrial, a humanidade viu-se atrelada a um modelo hegemônico de produção e consumo que coisifica o mundo de acordo com as regras e valores de mercado e que se ergue por cima das leis da natureza e do sentido de existência. Um olhar sobre os textos de Ana Paula Maia permite observar essa lógica produtivista de mercado em ação, isto é, em vias de exploração física e psíquica do humano e do animal.

O que emerge do espaço de sentido da escrita é esse vivente capturado em sua vulnerabilidade, em sua existência precária, e inscrito dentro de uma racionalidade econômica para ser vendido tanto os humanos quanto os animais - como força de trabalho e mercadoria. Ambos os seres são vítimas de um mesmo mecanismo que transforma os corpos em mercadoria e em valor, afinal, independentemente de qualquer diferença de espécie, tudo é capturável ou capitalizável.

Essa generalização que as narrativas encenam ilustra um dispositivo da biopolítica. Trata-se de um conceito desdobrado por Foucault ao longo da década de 1970 e que diz respeito ao poder concentrado nas políticas públicas governamentais, ou seja, na figura do Estado; mas não mais para promover simplesmente a docilização dos corpos individualizados, e sim para

\footnotetext{
${ }^{1}$ Maia (2013, p. 126).
} 
regulamentar o corpo enquanto espécie e com vistas à otimização das forças produtivas da própria vida (Murray e Whyte, 2011, p. 36).

Dessa forma, não há uma natureza que não esteja atravessada pela gestão bioeconômica, não há um exterior que não esteja capturado desde sua própria concepção pelo capital, pois a lógica do mercado só reconhece duas "espécies": proprietários e propriedade. Logo, qualquer corpo vivente pode ser apropriável em prol de um cálculo econômico.

Nos romances de Ana Paula Maia, a biopolítica surge na reflexão sobre a gestão da vida e da morte, em que viver e morrer podem ser apostas diferentes, mas são contínuas na operação do capital. Dentro das narrativas, essa ideia se concretiza de forma mais evidente a partir dos espaços ocupados pelos personagens, os quais separam física e simbolicamente essas duas zonas, vida e morte: o matadouro clandestino em Entre rinhas de cachorros e porcos abatidos, a fazenda de criação e abate em De gados e homens, o crematório em Carvão animal e até a própria colônia penal em Assim na terra como embaixo da terra - que foi um cemitério há tempos e ainda enterra seus mortos nos seus arredores.

Contudo, mais do que essas duas zonas distintas, o que os romances problematizam é o entremeio delas, onde, de fato, os homens se localizam e ali se abismam. É aqui que podemos enxergar a reinterpretação de Agamben sobre a ideia de biopolítica, que, segundo ele, não está na noção do poder soberano, em que o Estado "faz morrer e deixa viver": "matar, de maneira espetacular, os que ameaçassem seu poderio, e deixar viverem os demais"; nem no conceito de biopolítica de Foucault e Arendt, em que o Estado "faz viver e deixa morrer": "cuidar da população, da espécie, dos processos biológicos, otimizar a vida. Gerir a vida, mais do que exigir a morte" (Pelbart, 2007, p. 24). Para o filósofo italiano, o Estado "faz sobreviver", isto é, ele não investe nem na vida, nem na morte, mas na sobrevida, gerando sobreviventes e reduzindo o homem a uma dimensão residual, ao seu mínimo biológico.

São várias as cenas que mostram as personagens lidando com essa vida residual, com a "falta" em todos os níveis de assistência do Estado. Como consequência, as personagens revidam de forma insurgente, conforme conclui Daniela Meireles, em seu artigo "Rinhas de humanos: violência e negação de cidadania em Entre rinhas de cachorros e porcos abatidos de Ana Paula Maia", ao analisar a violência como forma de agência perversa que gera maneiras abjetas de inclusão na sociedade de consumo:

Matar cães, porcos ou homens significa, no cotidiano dessas pessoas, uma forma de retirar obstáculos de seus caminhos e, ao atingirem seus objetivos, alcançam um simulacro de cidadania. Eles não esperam pela ajuda e pela justiça que nunca virão e "arregaçam as mangas" para fazer valer sua cidadania sem se importarem com quantas vidas terão que perecer das formas mais violentas e grotescas como o romance nos revela (Meireles, 2015, p. 215).

Mas as histórias desses personagens não os obrigam a operar só com a falta ou com o pouco, eles precisam também lidar com os restos produzidos por quem pouco se importa com o destino deles, nem por eles quer ser responsável, como o de uma mulher morta no lixão: "Era um fiapo que assemelhava-se a um pedaço de carne defumada. Seca e escura. Eram despojos humanos misturados a restos de lixo orgânico, embalagem tetra pak e latas de ervilha" (Maia, 2009, p. 131). É dessa forma que as narrativas deflagram uma pungente estética centrada nos restos e na ruína.

Por restos, entendemos o consumo do consumo, isto é, o consumo daquilo que não é mais útil para a sociedade. Dentro desse viés, a novela $O$ trabalho sujo dos outros e o romance Carvão animal são os símbolos mais explícitos dessa estética, pois os conflitos giram em torno do manejo dos restos. Quando os lixeiros entram em greve, a cidade simplesmente sucumbe, e quando o forno do crematório explode, é preciso dar cabo da superlotação dos 87 corpos. Ambos os conflitos só são resolvidos no momento em que a ordem de manejo desses resíduos é restaurada, isto é, quando a greve acaba e quando os corpos são incinerados nos fornos de outra carvoaria.

Por ruína, queremos apontar para a decrepitude desse mundo, onde a coloração da água da torneira é bege, a farinha de trigo já está com bicho, a geladeira não dá vazão no calor, o rádio chia, a luz ou crepita ou está queimada, o detector de metais não funciona, o liquidificador de cozinha substituiu o deteriorado triturador de cinzas do crematório, o telhado da casa é forrado 
com folhas de latão e o do alojamento permanece danificado desde o temporal, as paredes estão descascadas e têm rachaduras enormes do teto ao chão, a placa de madeira da entrada da fazenda de Seu Milo se mantém suspensa só por um lado, o escritório é espremido e fica ao lado do setor de bucharia do matadouro, o rádio do carro está quebrado, só um limpador de parabrisa funciona, os pneus do caminhão são carecas e o para-choque é enferrujado, a caminhonete não funciona há mais de dez anos, a retroescavadeira solta mais fumaça que uma carvoaria, a fumaça preta que sai do escapamento da kombi é maior que a poeira da estrada, a rua é esburacada com algum vestígio de asfalto colocado há seis anos e a ponte que só permite a passagem de um carro por vez está quebrada.

Se os espaços são rotos, os corpos estão deteriorados. Para citar alguns personagens: Edgar Wilson, como um cão de rinha, carrega cicatrizes e lacerações no corpo, e quando trabalhava nas minas de carvão, tinha tom de pele amarelado e encardido e fuligem na saliva e nos olhos; Gerson tem um quadro avançado de doença renal crônica, assim como sua irmã, que, além disso, também tem câncer; Erasmo Wagner, que já foi picado por rato e bicado por urubu, tem cheiro azedo, unhas imundas, barba suja, dentes podres e dor na coluna que se agrava; Alandelon é jovem, nem se aposentou e já sofre com as sequelas de seu trabalho quebrando asfalto, toma analgésicos a cada oito horas para suportar o zumbido e as dores de cabeça e está ficando surdo; Bronco Gil acidentalmente perdeu um testículo em um ritual de iniciação à vida adulta e perdeu um olho em um atropelamento; Valdênio, depois de ser jogado da laje de um pavilhão da colônia penal, caminha arrastando a perna esquerda sequelada e com ajuda de uma bengala; Ernesto Wesley sofre de uma analgesia congênita, que o impede de sentir dor; Ronivon tem os pulmões enfraquecidos pelo constante choque entre as altas temperaturas do forno do crematório e a água gelada que precisa tomar para suportar o calor; enquanto os carvoeiros "são cegos, surdos e mudos pelas cinzas [...]. São todos homens e sombras" (Maia, 2011, p. 118).

Estaríamos aqui diante da figura do muçulmano descrita por Agamben, designação terminal dada àqueles sobreviventes nos campos de concentração? Embora ali se tratasse de judeus, eles assim eram chamados nos campos porque suas vidas já estavam entregues ao destino, como em um suposto fatalismo islâmico. O muçulmano era o cadáver ambulante, um feixe de funções físicas nos seus últimos sobressaltos, exausto demais para compreender a morte que o esperava, esvaziado demais para que pudesse sequer sofrer. É sobre essa vida, reduzida ao contorno de uma mera silhueta, como diziam os nazistas ao se referir aos prisioneiros, que aparece a perversão de um poder que não elimina o corpo, mas o mantém numa zona intermediária entre a vida e a morte, entre o humano e o inumano: o sobrevivente (Pelbart, 2007).

Essa condição de sobrevivente é um efeito generalizado da biopolítica contemporânea, que não se restringe aos regimes totalitários, e sim inclui plenamente a democracia ocidental. É por isso que aqui podemos enxergar os personagens de Ana Paula Maia, aos quais restam apenas - como adverte a autora na apresentação de Entre rinhas de cachorros e porcos abatidos, trabalhar duro - sobreviver com muito pouco, esperar o mínimo da vida e carregar seus fardos e o dos outros (Maia, 2009).

Apesar disso tudo, a construção das personagens não leva à vitimização completa delas, pois também coloca suas ações como fator de contribuição efetiva para a situação em que se encontram, como reconhece Seu Milo: "Ninguém está impune. Todos são homens de gado e sangue" (Maia, 2013, p. 38). As personagens, de forma consciente, explícita e sem culpa, não só mantêm práticas ilícitas e não éticas, como também não demonstram perspectiva de mudá-las: "Bronco Gil não é um homem bom e sabe disso" (Maia, 2017, p. 27); e Edgar Wilson, apesar de sua fé religiosa e de sua complacência para com os animais que mata, "sabe que sua própria violência nunca permitirá que um dia veja a face do Criador. Poderia se redimir, mas nunca se esforçou para isso" (Maia, 2013, p. 85).

Um exemplo dessa prática está em De gados e homens, quando Zeca não segue as normas do abatimento "sem crueldade" estabelecidas por Edgar Wilson e, então, torna-se um animal como os outros animais: abatido como um gado e morto sem ser assassinado.

Edgar Wilson entra no banheiro do alojamento. Espera que reste apenas o Zeca no banho. Com a marreta, sua ferramenta de trabalho, acerta precisamente a fronte do rapaz, que cai no chão em espasmos violentos e geme baixinho. Edgar Wilson faz o sinal da cruz antes de 
suspender o corpo morto de Zeca e o enrolar num cobertor. Nenhuma gota de sangue foi derramada. Seu trabalho é limpo. No fundo do rio, com restos de sangue e vísceras de gado, é onde deixa o corpo de Zeca, que, com o fluxo das águas, assim como o rio, também seguirá para o mar (Maia, 2013, p. 21).

De forma semelhante, termina o percurso de Pedro, morto, esquartejado e vendido como porco por Edgar Wilson no abatedouro clandestino de Entre rinhas de cachorros e porcos abatidos; assim como o dos prisioneiros caçados como javalis pelo rifle de Melquíades em Assim na terra como embaixo da terra.

Chama a atenção também nessas duas cenas a zoomorfização das personagens vítimas, uma estratégia utilizada pela escritora para lançar esses homens na mesma esteira de tratamento dos animais. Essa aproximação do universo comportamental e espacial entre ambos os grupos é recorrente em todos os seus romances.

Seu Milo rosna e berra; Melquíades fareja e é daltônico como os javalis; Helmuth tem olhos de peixe morto; Seu Gervásio rumina; J. G. é comparado a um bom cachorro, com quem se pode permanecer horas ao lado em silêncio e satisfeito; Seu Cristóvão cresceu alimentando-se tanto de porco que se reconhece como parte do animal; a irmã de Gerson é comparada a uma porca, assim como Rosemery; Valtair se sente como um cão por toda a vida; Erasmo Wagner tem a pele com textura de torresmo de porco e é estéril feito uma besta; Bronco Gil se sente uma besta na maior parte do tempo e mija feito um jumento; Pablo se sente o próprio jumento; e Edgar Wilson cicia, tem visão de morcego e foi criado feito cão de rinha.

Além dessas especificidades de cada personagem, há também as de grupo: as brigas territoriais entre os homens tal como ocorre com os cães; a astúcia e a violência dos homens comparadas a dos javalis; os presos da ala de segurança máxima vistos como cães perigosos que precisam de isolamento; os peões assemelhados aos arredios jumentos; e a colônia penal que, assim como o alojamento da fazenda de Seu Milo, é vista como um curral: "Ambos os confinamentos, de gado e de homens, estão lado a lado, e o cheiro, por vezes, os assemelham. Somente as vozes de um lado e os mugidos do outro é que distinguem homens e ruminantes" (Maia, 2013, p. 20).

Contudo, a presença dos animais nos romances não está simplesmente a serviço do homem, no sentido de funcionar como uma forma de acentuar sua desumanização ao colocar sua vida no mesmo patamar de igualdade à dos animais. Podemos perceber também um manifesto que poderia se aproximar do abolicionismo animalista. Mas, de fato, não encontramos "jaulas vazias" em Ana Paula Maia; sua literatura se restringe a expor e problematizar um especismo elitista e eletivo, sem alçar os voos libertários do abolicionismo animalista. Mas suas obras talvez não tenham esse alcance porque o grande impasse estaria no fato de a libertação dos animais só ser possível se a dos homens também fosse, porque as formas de dominação estão sempre inter-relacionadas.

Essa visão de animais como propriedade, seja para fins de consumo ou diversão, sustenta não somente a ordem antropofalocêntrica, mas também as desigualdades socioeconômicas. Peggy Sanday, em uma pesquisa sobre mais de cem culturas não tecnológicas, conclui que as economias de base agrícola têm mais probabilidade de serem igualitárias, enquanto que aquelas alicerçadas na produção de carne estão assentadas nas desigualdades de classe e de sexo: uma das "características das economias dependentes sobretudo do processamento de animais para alimento incluem: segregação sexual nas atividades de trabalho, com as mulheres trabalhando mais do que os homens" e, ainda, em uma "ocupação menos valorizada" (Adams, 2012, p. 97).

Na Fazenda de Seu Milo, a condição dos trabalhadores (longas jornadas de trabalho, péssimas condições do alojamento e salário insuficiente) somada a dos moradores dos arredores, que disputam as sobras das carnes fornecidas para a fábrica de hambúrguer, também é desoladora: “Tonho despeja um saco com pedaços gordos da vaca aos pés das mulheres, que precisam disputar com uma matilha de cães famintos que rodeiam o matadouro" (Maia, 2013, p. 58).

Em suma, esse tipo de economia global absorve práticas que estabelecem desigualdades de classe e sustentam a exploração dos grupos mais fracos, o que inclui não só as mulheres, mas os/as trabalhadores/as e a própria natureza. Nas obras de Ana Paula Maia, defrontamo-nos com o 
testemunho de um gesto reiterado na cultura contemporânea, a saber: a alteridade animal e a humana usurpadas pelas tecnologias biopolíticas de separação, contenção e capitalização.

Diante disso tudo, esses romances rompem com a leitura mais fácil, que seria pensar que se trata de homens animalizados, afinal, será que não estamos diante das falhas dessa lógica biopolítica com vantagens para poucos e que reduzem os animais e humanos a um mesmo plano, o do mero sobrevivencialismo imposto e que sufoca a individualidade de cada um?

\section{"Dentro deles existe apenas escuridão": 2 do real à escrita literária contemporânea}

No livro Bem-vindo ao deserto do Real! (2003a), que reflete sobre o confronto com o real a partir dos acontecimentos e consequências do 11 de setembro, Žižek nos mostra que não experimentamos a realidade como uma ordem estática, plena e sem fissuras, ela é sempre uma instância incompleta, que camufla o que a ela pertence e não pode ser expressa, apenas sentida. As personagens de Ana Paula Maia percorrem essas fissuras, levando o/a leitor/a a ter contato também com as dimensões foracluídas de sua realidade, isto é, com significantes que foram rejeitados e excluídos para fora do universo do sujeito. Sobre isso, podemos trazer aqui a reflexão do narrador em $O$ trabalho sujo dos outros:

Após um certo tempo rasgando asfaltos, sente que tudo em sua vida caminha para baixo. Tem costume de abrir pequenos buracos no quintal, cavar a comida, afundar o dedo em bolos confeitados e retirar o miolo do pão. Alandelon gosta mesmo de cavar. Desde pequeno, lembra-se disso. Quando olha para alguém, ele também cava. Seus olhos são um par de cavadeiras, ele olha para alguém e imediatamente começa a cavar. A maioria das pessoas quer seguir adiante, subir na vida. Ele deseja descer, afundar-se num buraco, pois tem a impressão que numa fenda subterrânea encontrará algo que lhe pertence, mas não sabe o que exatamente (Maia, 2009, p. 137).

Há, nessa novela, um episódio muito ilustrativo do retorno do foracluído, quando Erasmo Wagner está pronto com o facão amolado para matar o bode Tonhão, mas paraliza diante da lembrança ali suscitada, a do assassinato do "velho miserento" Mendes, molestador e assassino. Anos depois do crime cometido por ele próprio, descobre que a vítima era seu pai:

Erasmo Wagner segura o bode pelos chifres. Olha-o nos olhos. Lembra-se do velho Mendes. Então para. Não consegue continuar. [...]. Diante de Tonhão, olha-o novamente nos olhos e lá está o velho Mendes outra vez. Erasmo Wagner apoia-se na árvore e deixa o corpo afrouxar. Acreditava que havia terminado aquela história ao ter sacrificado alguns anos de sua vida em troca de pagamento por seu crime. Ter matado o velho com uma lasca de ferro no pescoço lhe parecia bem justo aos olhos de sua própria justiça, mas havia algo mais. Que retornou envolto ao hirco de um bode premiado.

- O que foi? - aproxima-se Edivardes.

- Não tô conseguindo matar esse bode - responde Erasmo Wagner, ofegante.

- O que tá acontecendo com você?

- Não sei (Maia, 2009, p. 124).

"Não sei" é o único modo como Erasmo Wagner conseguiu expressar sua experiência de ter trespassado sua realidade sustentada pela fantasia e, então, ter entrado em contato com o real. De acordo com Žižek (2003a), o real faz parte da tríade imaginário (fantasia), simbólico (realidade) e real, que são conceitos psicanalíticos de Lacan atualizados pelo filósofo para compreender os campos social, político, econômico e cultural, ou seja, a relação entre sujeito e mundo. Trata-se de três instâncias interdependentes, como três anéis de um nó borromeano, cujos três círculos têm a mesma importância e cujo entrelaçamento se dissolve caso um deles seja removido.

Para explicar essas instâncias, Žižek (2010, p. 16-17), em Como ler Lacan, que apresenta a psicanálise como método de leitura pertinente dos fenômenos da atualidade, recorre ao exemplo do jogo de xadrez. As peças, isto é, a forma como elas são modeladas e o nome que recebem são do domínio do imaginário, tanto que "é fácil imaginar um jogo com as mesmas

${ }^{2}$ Maia (2013, p. 35). 
regras, mas com um imaginário diferente". As regras do jogo, como a função atribuída a cada peça, "definida apenas pelos movimentos que essa figura pode fazer", pertencem à dimensão do simbólico. E ao real compete "toda a série complexa de circunstâncias contingentes que afetam o curso do jogo: a inteligência dos jogadores, os acontecimentos imprevisíveis que podem confundir um jogador ou encerrar imediatamente o jogo".

O imaginário, portanto, corresponde à criação de imagens que um indivíduo faz sobre pessoas e situações e que vai se manifestar no simbólico. Este, por sua vez, diferentemente do imaginário, não é uma esfera abstrata, mas essencialmente prática, pois é o lugar onde o sujeito socializa, cria e pertence a códigos e regras que devem ser seguidos, conscientemente ou não, para que a vida em sociedade seja compreensível. Já o real não tem uma estrutura discursiva de manifestação, nem pode ser traduzido por uma lógica, ele apenas tem uma presença inconscientemente sentida (Žižek, 2010).

Assim, podemos entender melhor a experiência com o real de Erasmo Wagner, que se sente "redimido pelo sofrimento que já passou, pela pena que cumpriu. Mas existem camadas profundas da alma, que não são atingidas por açoite humano, nem por desgraças terrenas" (Maia, 2009, p. 141). Essas camadas são as fissuras dentro de sua própria rede simbólica, um espectro intraduzível pelas outras camadas, mas que persiste inerente a elas, enviando sintomas de sua resistência. Tanto que, mesmo já tendo cumprido a pena de seu crime, ele ali, diante do olhar do bode em carne e osso, surpreende-se ao enxergar seus confins.

Importante entender que, a partir do momento em que o indivíduo busca nas coordenadas simbólicas que ele já possui elementos que expliquem a experiência da esfera do real vivenciada, já não estamos diante dela, mas, sim, de uma experiência de ressimbolização. Entretanto, é justamente dessa forma que o real se torna possível, quando se volta ao simbólico e o ressignifica. Assim conclui a filósofa eslovena lacaniana Alenka Zupančič, em seu livro Ethics of the real (2011), que discute a ética a partir do diálogo divergente entre a filosofia de Kant e a psicanálise de Lacan:

De acordo com Lacan, o real é impossível, e o fato que "ele acontece (a nós)" não refuta sua "impossibilidade" básica: o real nos ocorre (nós o encontramos) como impossível, como "a coisa impossível" que transforma nosso universo simbólico do avesso e nos leva à reconfiguração desse universo. Daí a impossibilidade do real não impede que ele tenha efeito no reino do possível. É quando a ética entra em jogo, na questão que nos é imposta pelo encontro com o real: irei agir em conformidade com o que me deixou "deslocado", estarei pronto para reformular o que até agora tem sido o alicerce da minha existência? (Zupančič, 2011, p. 235, tradução nossa).

É por isso que o contato com o real é sempre traumático, porque, estando ele para além do que pode ser representado na esfera simbólica, rompe com a lógica da realidade do indivíduo. Segundo Pedro Laureano (2015, p. 178-179), em seu artigo "Uma breve introdução ao pensamento de Slavoj Žižek", "uma questão mínima como pedir pela redução das tarifas de ônibus já coloca em xeque todo nosso sistema político e social, já significa esta fissura na teia das aparências que Žižek apresenta como sendo o real." Portanto, tudo aquilo que desestabiliza os parâmetros e discursos basilares do sistema vigente, tudo que racha no âmbito do simbólico empenhado em mostrar-se coeso já é o real irrompendo.

Como resultado dessa perturbação, o sujeito pode tomar dois caminhos: a fuga do real ou a paixão por ele. A fuga do real é o desejo de amenizar a existência dessa instância excessiva: "Jacques Lacan afirma que a atitude espontânea do ser humano é a de que 'não quero saber disso' - uma resistência fundamental contra saber demais" (Žižek, 2003a, p. 83). Já a paixão pelo real - termo cunhado por Alain Badiou - é quando "a busca pelo evento traumático não é mais evitada, e sim explorada [...] - uma tentativa de atingir o 'núcleo duro' e autêntico dos acontecimentos" (Fabreti, 2013, p. 51).

Nos romances de Ana Paula Maia, podemos identificar melhor a paixão pelo real. Diante de um contexto biopolítico que não promove a vida, de um Estado que não assiste, de um trabalho que pouco assegura condições básicas, de uma prisão que não cumpre a pena, mas a morte, os personagens insurgem de duas maneiras: em atos que mostram as falhas da ordem simbólica, 
exibindo, assim, sua inconsistência, como é o caso da greve dos lixeiros e a fuga da colônia penal; mas sobretudo em atos de destruição, que revelam uma vontade do indivíduo em escapar dessa realidade inerte, repetitiva e sufocante na qual ele pouco sente ou pouco existe.

Em ambos os casos, temos uma experiência de encontro com o real - ou somente com seu efeito -, pois a transgressão, como Žižek afirma em entrevista, potencialmente significa a experiência limite que nos coloca diante do real, seja na figura da violência política ou da sexualidade sadomasoquista (Zizek, 2003b).

Por isso as personagens pouco falam de si, pouco sabem o que sentem, porque estão em constante contato com o real, que é difícil de simbolizar, ainda mais "para homens como eles", "criados em silêncio" e cujas "palavras compõem um vocabulário escasso"; e também difícil de digerir, sobretudo quando se têm dentes podres ou ausentes na boca:

Enfia os dois dedos na boca e, gemendo abafado, arranca o molar podre. O dente fede e está escuro. Enfia um punhado de papel higiênico para conter o sangue desmedido. Volta para a mesa. Sua cerveja está quente. Sua boca cheia de papel. Erasmo Wagner retira o punhado de papel da boca. Está empapado de sangue. Toma um gole de cerveja, faz um bochecho e engole (Maia, 2009, p. 79).

Isso explica a necessidade de um narrador predominantemente onisciente, para que ele possa ressimbolizar as experiências traumáticas vivenciadas pelos personagens e torná-las deglutíveis, ainda que parcialmente. Diante do real que irrompe metaforicamente no ato desesperado e solitário da personagem em enfiar os dois dedos na boca e arrancar o próprio dente, só o narrador para estancar esse sangue, e o faz preenchendo com o papel, a escrita.

Mas, para que isso resguarde um pouco do efeito do real, afinal, a tradução das experiências em palavras já o deixa escapar, a atenção dada a algumas estratégias da linguagem cumpre um importante papel. A escrita de Ana Paula Maia flerta com a velocidade advinda da literatura virtual, a qual faz parte da trajetória inicial da escritora, que escrevia e publicava folhetins em seu blog; com a visualidade cinematográfica, decorrente também de sua passagem como roteirista; e com a narrativa bruta e crua característica da vertente realista/naturalista, que não oferece a polpa sem o desconforto de uma casca dura, como o feijão mal cozido de Penha: "Zé ouve tudo enquanto tira uma casca de feijão do dente, levando o dedo até o fundo da boca. Constata que a casca está dura e que sua mulher não o cozinhou por tempo suficiente" (Maia, 2009, p. 51).

Além dessas estratégias que contribuem para a retirada das camadas ilusórias da realidade, facilitando o descortinamento das fissuras do simbólico e o encontro com o real, podemos citar ainda outro recurso muito presente. Trata-se de trazer luz ao "referente ausente", conceitochave utilizado pela ecofeminista Adams (2012), em A política sexual da carne, livro em que a autora utiliza o conceito para explicar o entrelaçamento da opressão das mulheres e dos animais. Segundo Adams (2012), da mesma forma que os termos referentes à carne (bife, hambúrguer, bacon, salsicha etc.) os mantêm distantes de qualquer ideia de que eles se referem a um animal em sua integralidade (vaca, boi, porco etc.); as mulheres também são transformadas em referentes ausentes após terem seus corpos retalhados em partes sexualizadas consumíveis (bundas, seios, pernas etc.). De modo geral, explica Adams:

o referente ausente pode ser qualquer coisa cujo significado original é solapado, ao ser absorvido numa hierarquia de significado diferente; nesse caso, o significado original do destino dos animais é absorvido numa hierarquia centrada no homem (Adams, 2012, p. 80).

Nos romances de Ana Paula Maia, essa mesma operação se processa com relação aos homens e aos animais, e a tudo a sua volta, como as profissões e os espaços. São inúmeras as estratégias criadas na sociedade para que a existência dessas categorias jamais seja percebida, ainda que saibamos que existem aterros sanitários, matadouros, prisões, carvoarias, bem como humanos e animais que ali trabalham e vivem - senão o lixo não seria recolhido, a carne não chegaria embalada em cortes na bandeja e haveria mais dificuldades no funcionamento do sistema penal e das indústrias termoelétrica e siderúrgica.

Uma dessas estratégias, além da distância física a que já estamos desses viventes e espaços, é a linguagem, que tende a converter a realidade material em metáforas controladas. É por isso 
que os romances de Ana Paula Maia rompem com o sobrecarregamento de metáforas, para justamente iluminar o referente ausente e nos colocar a par de seus processos de objetificação, retalhamento/fragmentação, consumo e descarte.

Podemos afirmar que o referente ausente em suas narrativas domina a metáfora, oferecendo, assim, ao/à leitor/a, nos termos de Žižek, uma dose de obscenidade para promover uma experiência com o real. E nos termos de Karl Schøllhammer (2013, p. 122-123), em seu livro Cena do crime: violência e realismo no Brasil contemporâneo, estamos aqui diante de uma literatura pornográfica, por revelar "temas e objetos ligados a tudo o que é excluído e proibido em nossa cultura - não só o sexo, que hoje já não recebe o mesmo estigma cultural, mas a miséria, a violência, a loucura e a morte".

Isso tudo retoma, por sua vez, elementos do realismo ou do "realismo refratado", segundo Tânia Pellegrini (2007), já que o real $^{3}$ nunca é apreensível, ele é sempre uma realidade traduzida, deglutida, modificada por depender de um meio para se tornar cognoscível.

É dessa forma que podemos entender os romances da escritora, eles também lançam para a realidade das personagens possibilidades de expansão do horizonte antes apresentado apenas pela conjunção entre simbólico e imaginário. Daí a importância do encontro com o real, pois, ainda que essa experiência seja traumática, ela permite olhar para o escuro de seu tempo de que fala Agamben (2009), em O que é o contemporâneo, que desvincula a ideia tradicional de contemporaneidade da noção de tempo linear. Segundo o filósofo:

Contemporâneo é aquele que mantém fixo o olhar no seu tempo, para nele perceber não as luzes, mas o escuro. Todos os tempos são, para quem deles experimenta contemporaneidade, obscuros. Contemporâneo é, justamente, aquele que sabe ver essa obscuridade, que é capaz de escrever mergulhando a pena nas trevas do presente. Mas o que significa "ver as trevas", "perceber o escuro"? (Agamben, 2009, p. 62-63).

Olhar para o escuro na literatura, segundo Agamben (2009, p. 63), é pensar na neurofisiologia dos olhos: "a ausência de luz desinibe uma série de células periféricas da retina, ditas precisamente off-cells, que entram em atividade e produzem aquela espécie particular de visão que chamamos o escuro". Produzir o escuro, portanto, não é mero resultado da ausência de luz, como se fosse uma atividade passiva ou inerte, trata-se de um produto da ação sensível dessas células.

Ana Paula Maia assim também se coloca em ação, sem se deixar cegar pelas luzes de seu tempo, percebe o obscuro do presente, as vértebras quebradas, o dorso fraturado, como no trecho do poema de Osip Mandel'štam, que se intitula "O século": "Meu século, minha fera, quem poderá / olhar-te dentro dos olhos / e soldar com seu sangue / as vértebras de dois séculos? / Enquanto vive a criatura / deve levar as próprias vértebras, / os vagalhões brincam / com a invisível coluna vertebral" (Agamben, 2009, p. 60).

Em todas as narrativas da escritora, percebemos um traço distintivo, a saber, a preferência por temas subterrâneos, ou seja, aqueles que, embora presentes no cotidiano, são ocultados de rodas de conversa, são ignorados pela sociedade em geral e pelo poder público.

Trata-se de uma abordagem pouco comum na literatura de autoria feminina, como mostram os resultados da pesquisa "Literatura brasileira contemporânea de autoria feminina: escolhas inclusivas?", coordenada por Lúcia Zolin na Universidade Estadual de Maringá. A partir de um questionário, o projeto analisou romances publicados nos anos 2000 a 2015 por três grandes editoras nacionais, Companhia das Letras, Record e Rocco. De posse dessas informações estatísticas referentes à aparência e a condições físicas, ao trabalho e à condição socioeconômica, educação, sexualidade, relações sociais, espaço, maternidade/paternidade, temática, foi possível montar, com ajuda do software Sphinx Survey, um banco de dados sobre as preferências das autoras nesses romances. O objetivo central dessa pesquisa, que teve como foco o modo de construção de cada um das 618 personagens consideradas fundamentais para o

\footnotetext{
${ }^{3}$ Os termos real, realidade e realismo utilizados por Tânia Pellegrini não se referem ao real de Žižek, mas, sim, à esfera literária de modelo de representação.
} 
desenrolar da trama dos 151 romances constituintes do corpus, "foi perscrutar se as escolhas dessas escritoras quando do desempenho da tarefa de representar o outro são inclusivas, no sentido de trazerem para a cena literária práticas e discursos vedados a seguimentos sociais marginalizados e/ou de minorias" (Zolin, 2018, p. 3).

Entre os resultados ${ }^{4}$ que importam aqui destacar, percebemos a tendência das autoras em se autorrepresentarem nas narrativas por meio da presença predominante de mulheres (aproximadamente 60\%) - sobretudo na posição de protagonistas (aproximadamente 70\%). Ana Paula Maia, não obstante, faz o inverso, investe em personagens masculinas, o que a afasta dessa trajetória de escrita que busca não só tornar visível a mulher autora e a mulher personagem, mas também agenciar representações vindicativas de mulheres. Aliás, elas pouco figuram em seus textos e, quando o fazem, restringem-se a personagens tipo, como a mãe, a babá, a namorada, a amante, a prostituta, a faxineira, a secretária, a cozinheira ou as miseráveis famintas que habitam os arredores do matadouro.

Mesmo pouco presentes, elas não escapam da violência que ronda as narrativas, como um animal à espreita do predador: a mãe de Bronco Gil foi estuprada pelo pai; a vizinha Dona Zema morreu envenenada pela própria armadilha criminosa que preparou; a irmã de Gerson morreu ao ter o rim retirado a canivete por Edgar Wilson; Rosemery foi esquartejada pelo namorado; e a filha de Ernesto Wesley morre em um acidente de carro possivelmente influenciado pela embriaguez do motorista que é seu irmão. Mas essa não é a realidade em cerca de $85 \%$ das personagens dos romances analisados, seja em qualquer um destes papéis: vítima, criminoso/a, cúmplice, familiar ou parente, parceiro/a amoroso/a ou só amigo/a.

Essa presença quase nula das mulheres na literatura de Ana Paula Maia, não obstante, tem uma função na narrativa. Trata-se de uma estratégia para compor um universo falocêntrico tradicional em suas histórias, no qual quem habita os espaços e movimenta as engrenagens dos matadouros, dos crematórios, das carvoarias, dos destinos do lixo e habitam as prisões são os homens predominantemente, e não as mulheres. Contudo, convém ressaltarmos que isso não significa dizer que elas não possam ocupar tais espaços, como, de fato, já o fazem; trata-se apenas de uma estratégia literária para acentuar o androcentrismo em suas obras.

E aqui já estamos diante de outro elemento distinto que configura seus romances, a saber, o espaço: em vez do ordinário mundo urbano, que compõe cerca de $85 \%$ das narrativas escritas por mulheres, é o isolamento do espaço rural não idílico que prevalece, mas sem configurar um universo caipira e sem uma localidade fixa. À semelhança dos prisioneiros da colônia penal, as personagens "estão no meio de lugar nenhum" e "do lado de fora, além da vastidão e dos espaços vazios, existe o silêncio empurrando-os para o nada" (Maia, 2017b, p. 77). São topografias pouco literalizadas, literalmente obscenas, no sentido de excluídas das representações literárias convencionais. Diante dessa escassez, deixa-se de emergir uma dimensão social, política e ética problemática, associada a esses espaços em que a exceção é o elemento constitutivo fundador. Aliás, é justamente por meio da topografia que se materializa o exercício paradoxal da soberania, pois é ela que circunscreve o espaço que inclui e exclui.

Mas, se as mulheres são escassas nos romances da autora, os animais são abundantes. Sua presença permanente, e não episódica, cuja existência é tratada enquanto tema, e não meramente como metáfora ou alegoria, promove uma abertura a discussões proeminentes da contemporaneidade que tendem a permanecer limitadas ou frequentemente silenciadas nos discursos teórico-críticos suscitados e desestabilizados pela e na literatura de autoria feminina. Entre os 151 romances constituintes do corpus da pesquisa, somente os de Ana Paula Maia e o de Regina Rheda alcançam essa abordagem crítica acerca dos animais, ou seja, trata-se ainda de um tema pouco explorado na seara literária das mulheres.

Nessa mesma esteira de ausências, podemos citar a marca de aproximadamente $15 \%$ de personagens pobres e miseráveis, em contraposição a quase $85 \%$ de personagens da classe média e da elite, o que nos permite reiterar a conclusão de Regina Dalcastagnè (2002) em seu

${ }^{4}$ Para efeitos comparativos, os dados das personagens dos romances de Ana Paula Maia neste momento foram excluídos da base de dados. 
artigo "Uma voz ao sol: representação e legitimidade na narrativa brasileira contemporânea", o qual parte da inquietação diante da ausência quase absoluta de representantes de classes populares na narrativa brasileira contemporânea:

De maneira um tanto simplista e cometendo alguma (mas não muita) injustiça, é possível descrever nossa literatura como sendo a classe média olhando para a classe média. O que não significa que não possa haver aí boa literatura, como de fato há - mas com uma notável limitação de perspectiva (Dalcastagnè, 2002, p. 35).

Diante dessa realidade, não espanta chegarmos a um rol de profissões que se distancia do "trabalho sujo dos outros" que as personagens de Ana Paula Maia realizam, são elas: professor/a, empresário/a e estudante, para citar as três maiores ocorrências. Nem causa estranheza o fato de aproximadamente $28 \%$ dos personagens não apresentarem indícios de ocupação profissional.

Isso influi diretamente nas temáticas, que pouco problematizam a questão profissional, já que o conflito não está emaranhado nessa esfera ou, ao menos, não de forma incisiva, como assim podemos ver nos romances de Ana Paula Maia. A autora traz à baila a violência e questões sociopolíticas de classe, que juntos estão presentes em cerca de $10 \%$ dos romances analisados na referida pesquisa. A ordem são os conflitos mais restritos à família, ao amor e à sexualidade, que representam as maiores frações das temáticas nessas narrativas, totalizando aproximadamente $40 \%$ das ocorrências.

Convém ressaltar que, apesar dessas recorrências dentro da literatura de autoria feminina, elas não impedem que perspectivas sociais plurais sejam apresentadas, pois há também uma diversidade de experiências cotidianas dentro dessas realidades que permitem realizar leituras potencial ou efetivamente transgressoras em relação a modelos hegemônicos tradicionais. Contudo, é a partir desses dados que podemos justificar os deslocamentos de Ana Paula Maia em relação a essa órbita literária que pouco se arrisca pelos caminhos da violência e a adentrar universos para além do teto todo seu.

\section{Das singularidades: algumas considerações}

Se Agamben traz a gravura do banquete messiânico com os representantes da humanidade retratados com corpos humanos e cabeças de animais, em Ana Paula Maia, na capa de Entre rinhas de cachorros e porcos abatidos (Figura 2), temos um crânio humano e o corpo formado pelas imagens da cabeça de um cachorro e de um porco.

Diante de todas as discussões aqui empreendidas, podemos entender essa imagem não como uma reconciliação entre o humano e o animal, nem como uma animalização do homem ou uma humanização do animal, mas como vidas reduzidas e recortadas, como na figura, a um mesmo plano, que não é nem a de um, nem a de outro, pois ambos tiveram sua alteridade solapada.

Estamos aqui diante de viventes reduzidos a uma matéria inerte, a uma polpa de carne, músculos e ossos à mercê do sobrevivencialismo biológico que a gestão biopolítica promove. Corpos violentados em sua dignidade ontológica e reduzidos à noção exótica da besta, da fera ou da besta-fera, que são termos que sinalizam uma afetividade negativa, por ser atribuído a animais com uma potência voraz e altamente destrutiva, movidos pela pulsão.

E para problematizar essas questões que representam na literatura escrita por mulheres o escuro de Agamben, a estratégia em trazer à tona o referente ausente tem um grande efeito, pois consegue iluminar as fissuras desse contexto biopolítico e propiciar, assim, o encontro com o real. Esse é, possivelmente, o maior alcance de suas obras para a hipótese de subversão da escrita de autoria feminina, a qual, conforme revelam os dados da pesquisa acima referida, pouco enredam a realidade desses humanos e a desses animais, que muito se assemelham, mas em outro plano, o do gado laborans: abatidos diária e indistintamente pelo trabalho bruto e sujo, induzido pela máquina do capital, que os conduz em linha reta ao piquete, isto é, a uma vida sem um horizonte promissor. 


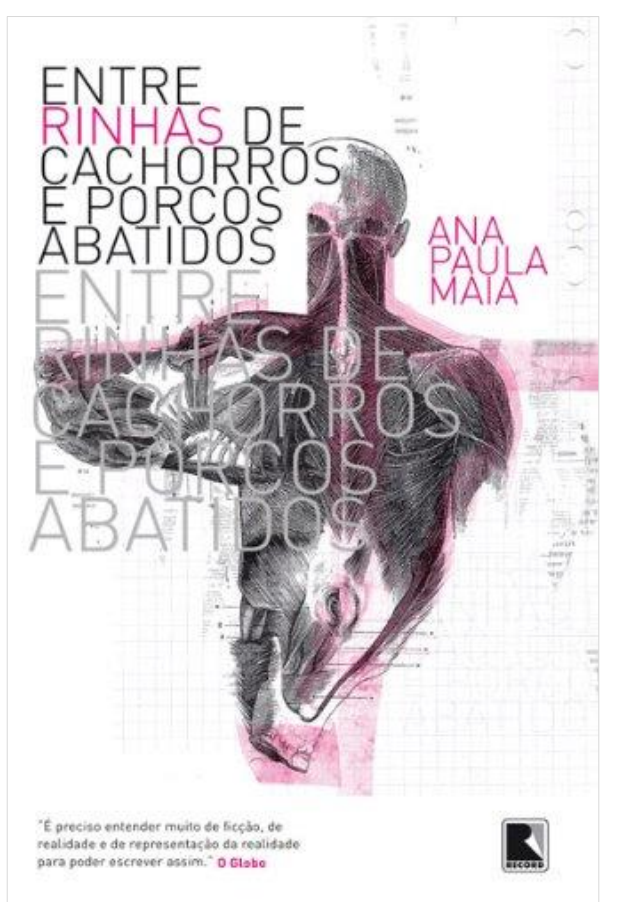

Figura 2 - Capa de Entre rinhas de cachorros e porcos abatidos Fonte: Maia (2009).

\section{Referências}

ADAMS, Carol J. (2012). A política sexual da carne: a relação entre o carnivorismo e a dominância masculina. Tradução de Cristina Cupertino. São Paulo: Alaúde. E-book.

AGAMBEN, Giorgio (2009). O que é o contemporâneo? Tradução de Vinícius Nicastro Honesko. Chapecó: Argos.

AGAMBEN, Giorgio (2017). O aberto: o homem e o animal. Tradução de Pedro Mendes. 2. ed. Rio de Janeiro: Civilização Brasileira.

DALCASTAGNÈ, Regina (2002). Uma voz ao sol: representação e legitimidade na narrativa brasileira contemporânea. Estudos de Literatura Brasileira Contemporânea, Brasília, v. 20, p. 33-77. Disponível em: https://periodicos.unb.br/index.php/estudos/article/view/8925. Acesso em: 15 fev. 2019.

FABRETI, Ariane Andrade (2013). Traumas e paixões da modernidade: o materialismo lacaniano lê Madame Bovary. 120 f. Dissertação (Mestrado em Letras) - Universidade Estadual de Maringá, Maringá, 2013. Disponível em: http://www.ple.uem.br/defesas/pdf/aafabreti.PDF. Acesso em: 11 fev. 2019.

LAUREANO, Pedro Sobrino (2015). Uma breve introdução ao pensamento de Slavoj Žižek. Analytica, São João del-Rei, v. 4, n. 7, p. 161-185, jul./ dez. Disponível em: https:// bit.ly/38dlvrb. Acesso em: 11 fev. 2019.

MAIA, Ana Paula (2009). Entre rinhas de cachorros e porcos abatidos. Rio de Janeiro: Record.

MAIA, Ana Paula (2011). Carvão animal. Rio de Janeiro: Record.

MAIA, Ana Paula (2013). De gados e homens. Rio de Janeiro: Record.

MAIA, Ana Paula (2017). Assim na terra como embaixo da terra. Rio de Janeiro: Record.

MEIRELES, Daniela Cristina Leal (2015). Rinhas de humanos: violência e negação de cidadania em Entre rinhas de cachorros e porcos abatidos de Ana Paula Maia. Krypton, n. 5/6, p. 208-216. Disponível em: https:// bit.ly/3riFaNS. Acesso em: 26 jan. 2019.

MURRAY, Alex; WHYTE, Jessica (2011). The Agamben dictionary. Edinburgh: Edinburgh University Press. 
PELBART, Peter Pál (2007). A vida desnudada. In: GREINER, Christine; AMORIM, Claudia (Org.). Leituras da morte. São Paulo: Annablume. p. 21-36.

PELLEGRINI, Tânia (2007). Realismo: postura e método. Letras de Hoje, Porto Alegre, v. 42, n. 4, p. 137-155, Disponível em: revistaseletronicas.pucrs.br/ojs/index.php/fale/article/download/4119/3120. Acesso em: 11 fev. 2019.

SCHOLLHAMER, Karl Erik (2013). Cena do crime: violência e realismo no Brasil contemporâneo. Rio de Janeiro: José Olympio.

ŽIŽEK, Slavoj (2003a). Bem-vindo ao deserto do Real! Cinco ensaios sobre o 11 de setembro e datas relacionadas. Tradução de Paulo Cezar Castanheira. São Paulo: Boitempo.

ŽIŽEK, Slavoj (2003b). A paixão pelo real. [Entrevista a] Vladimir Safatle. Folha de S. Paulo, Caderno Mais!, São Paulo, 30 nov. Disponível em: https://www1.folha.uol.com.br/fsp/mais/fs3011200304.htm. Acesso em: 11 fev. 2019.

ŽIŽEK, Slavoj (2010). Como ler Lacan. Tradução de Maria Luiza X. de A. Borges. Rio de Janeiro: Zahar.

ZOLIN, Lúcia Osana (2018). Estratégias de subjetificação na ficção contemporânea de mulheres: exílio, migração, errância e outros deslocamentos. Acta Scientiarum - Languagem and Culture, Maringá, v. 40, n. 2, p. 1-9. Disponível em: https:// bit.ly/3sKqjvK. Acesso em: 15 fev. 2019.

ZUPANČIČ, Alenka (2011). Ethics of the real: Kant and Lacan. 2. ed. New York: Verso Books.

\section{Nota}

Este artigo tem origem na tese de doutorado de Lígia de Amorim Neves intitulada Entre bandos e bestas: a literatura PANC de Ana Paula Maia, defendida em 2019 na Universidade de Maringá, sob orientação da profa. Lúcia Osana Zolin. 